\title{
ШЛЯХИ ПІДВИЩЕННЯ МОТИВАЦІЇ СТУДЕНТІВ ДЛЯ ПОКРАЩЕННЯ ЯКОСТІ НАВЧАННЯ НА КАФЕДРІ НЕЙРОХІРУРГІЇ І НЕВРОЛОГІЇ ОДЕСЬКОГО НАЦІОНАЛЬНОГО МЕДИЧНОГО УНIВЕРСИТЕТУ
}

\author{
А. С. Сон, В. В. Добровольський, Ю. І. Горанський, Г. В. Перькова, \\ О. М. Стоянов, О. П. Лебідь \\ Одеський наиіональний медичний університет
}

\section{WAYS TO INCREASE MOTIVATION OF STUDENTS FOR IMPROVING THE QUALITY OF EDUCATION AT THE DEPARTMENT OF NEUROSURGERY AND NEUROLOGY OF ODESA NATIONAL MEDICAL UNIVERSITY}

\author{
A. S. Son, V. V. Dobrovolskyi, Yu. I. Horanskyi, H. V. Perkova, \\ O. M. Stoyanov, O. P. Lebid
}

\section{Odesa National Medical University}

\begin{abstract}
У статті представлений аналіз методичних підходів щодо підвищення мотивації студентів для покращення якості навчання на кафедрі нейрохірургії і неврології Одеського національного медичного університету.
\end{abstract}

The article presents an analysis of methodological approaches to improve students' motivation to improve the quality of teaching at the Department of Neurosurgery and Neurology of Odesa National Medical University.

Вступ. В останні роки викладачі кафедри нейрохірургії і неврології Одеського національного медичного університету (ОНМедУ) досить часто зустрічаються з випадками пониженої мотивації деяких студентів до якісного опанування предмета нервових хвороб. Найбільша мотивація в студентів-іноземців, які після закінчення навчання у своїх країнах складають додаткові іспити, їх конкурентоспроможність перевіряється 3 перших самостійних кроків, крім того в Індії, Ізраїлі, арабських країнах лікар займає високий соціальний стан й отримує досить високі гонорари за свою працю. Тому студенти-іноземці уважно слідкують за якістю навчання. Болонська система, впроваджена в нашій країні, дає можливість широко впроваджувати в процесі навчання самостійну роботу студентів, яка разом з цим потребує певних навичок у студента (робота 3 технічними засобами, $з$ літературою, розподіл робочого часу та ін.) [1]. Саме тому деякі студенти, особливо на молодших курсах, зустрічаються з певними труднощами, низькою мотивацією до вивчення предметів. Найменша мотивація у студентів вітчизняних студентів-стоматологів та іноземних студентів з Сирії,
Лівії, Молдови, які не цілком усвідомлюють необхідність уважного опанування курсу нервових хвороб. Якість вивчення неврології цією категорією студентів в 2008 - 2010 роках була досить невисокою (23\% студентів не склали з першої спроби заключного тестового заліку в 2008 - 2009 навчальному році, $16 \%$ - в 2009 - 2010 навчальному році).

Тому сприяла низка факторів:

1. Високе навчальне навантаження не дає можливості зосередитися на одному предметі.

2. Студенти у своїй масі не спроможні зразу вибрати свою майбутню спеціалізацію, що позначається на мотивації до навчання взагалі.

3. Студенти, які зіткнулися з повсякденними труднощами практичного лікувального процесу та низькою оплатою праці своїх старших колег, швидко втрачають мотивацію до навчання широкого спектра предметів, необхідних для розширення кола знань в опануванні своєї майбутньої спеціалізації [2].

Саме тому проблема мотивації до вивчення предмета нервових хвороб на кафедрі вирішується комплексно. Поліпшує ії вирішення те, що до четвертого курсу, на якому вивчають курс нервових хвороб,

() А. С. Сон, В. В. Добровольський, Ю. І. Горанський та ін. 
Динаміка змін співвідношення студентів, які не склали залік із неврології 3 першої спроби, за останні три роки

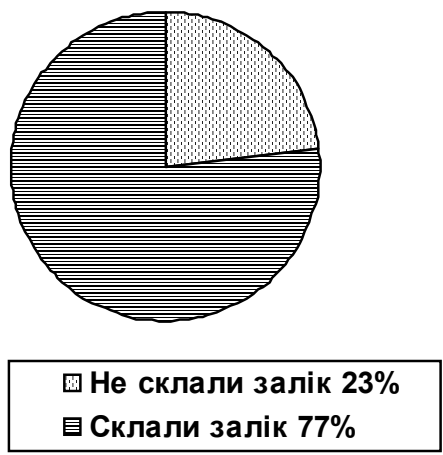

$2008-2009$ навчальний рік

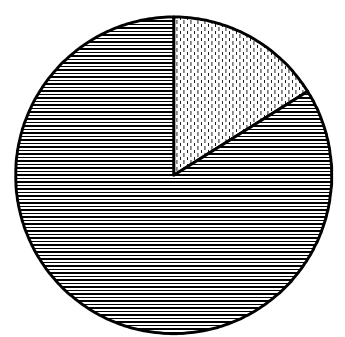

Не склали залік $16 \%$

目 Склали залік $84 \%$

$$
\begin{gathered}
2009-2010 \\
\text { навчальний рік }
\end{gathered}
$$

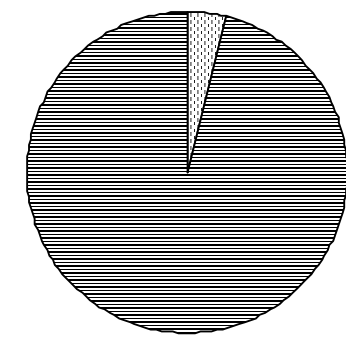

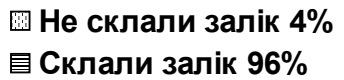

$$
\begin{gathered}
2010-2011 \\
\text { навчальний рік }
\end{gathered}
$$

більшість студентів вже визначились 3 метою отримання фаху лікаря та майбутньою спеціалізацією, розуміють важливість неврології для практичної діяльності лікаря будь-якої спеціалізації [3].

Основна частина. Вирішуючи проблему підвищення мотивації студентів до навчання, на кафедрі нейрохірургії і неврології ОНМедУ значна увага приділяється вивченню історії розвитку неврології, досягненням московської (Г. І. Сокольський, А. Я. Кожевніков, Г. І. Россолимо, Е. К. Сепп, Н. К. Боголепов), петербурзької (В. М. Бехтерев, М. П. Жуковський, М. І. Аствацатуров), одеської (Г. І. Маркелов, Г. Г. Соколянський, О. П. Король, Ю. Л. Курако) шкіл, їх видатних представників, а також новим науковим досягненням в галузі неврології світу, Україні, зокрема ОНМедУ.

При підготовці до лекцій, семінарів, конференцій викладачі використовують матеріали університетської та кафедральної бібліотек. Такий підхід дає можливість підняти авторитет університету й кафедри в очах студента. На наш погляд, необхідно повною мірою використовувати музей університету, де приділити увагу матеріалам з вивчення курсу нервових хвороб під час самостійної роботи студентів, ознайомлювати школярів та абітурієнтів під час днів відкритих дверей 3 досягненнями одеської неврологічної школи, досягненнями провідних науковців ОНМедУ.

Під час демографічного спаду, починаючи з 2011 року, це дасть можливість не тільки підвищити мотивацію, заохочувати до вивчення неврології, але й покращити відбір абітурієнтів до майбутніх студентів.

Настав час, коли процес мотивації повинен бути більш керованим та починатися він повинен ще $з$ середньої школи. Постійний зв'язок зі школою, попередній підбір студентів у середніх навчальних закла- дах, в тому числі спеціальних медичних, виступи там провідних фахівців кафедри та університету дали можливість більш якісному підбору студентів, створити установки на навчання, підвищити мотивацію й значно зменшити відсів студентів як під час навчання, так іпісля закінчення університету, а також підвищити здорову конкуренцію під час вступу до університету.

Одним з головних чинників підвищення мотивації до навчання, любові до професії став високий рівень підготовки викладачів кафедри до занять 3 студентами, де в першу чергу увага приділяється вивченню практичних навичок й умінь, клінічним розборам складних випадків.

Керівництво університету систематично виступає по телебаченню не тільки з медичних, але й з філософських тем. На кафедрі організовано обговорення публічних програм телебачення з метою доведення до студентів та розвинення їхнього кругозору. На кафедрі запропоновані виступи перед студентами на теми, що пов'язані з інформацією про науково-практичні досягнення клінічних кафедр університету. Головні напрямки в цих виступах, які часто приймають форму семінару, бесіди, з допомогою яких співробітники кафедри намагаються прищепити студентам повагу й любов до справи, якій вони збираються присвятити життя, що особливо важливо під час реформи медичної допомоги, та підвищення значення сімейного лікаря й набуття широких практичних знань.

На кафедрі впроваджено стенд з фотографіями кращих випускників, студентів “кружківців", переможців студентських олімпіад, учасників наукових конференцій молодих вчених з анотаціями їх досягнень.

На кафедру запрошуються для зустрічі зі студентами найбільш успішні неврологи та нейрохірурги, які виступають перед студентами, розкривають досвід 
роботи в практичній лікарській діяльності. Зокрема на лекціях, конференціях неврологів брали участь: Pavelka Kalvach (Czech Republic), Detlef Kompf (Germany), Laszlo Csiba (Hungary), Juha Hernesniemi (Finland), які, маючи багаторічний досвід роботи в медицині, прищепляли любов до професії, якій слугують.

В ОНМедУ та власне на кафедрі налагоджений зв'язок з низкою газет, де регулярно друкують матеріали про діяльність співробітників кафедри, їх успіхи в лікувально-навчальному процесі.

Іноземні студенти потребують особливого підходу до їх навчання, але мотивація до навчання в цієї категорії студентів досить висока. Вона обумовлена в першу чергу тим, що після приїзду до своєї країни вони мають повторно складати іспит, а успіху досягає лише кожний четвертий 3 них.

На кафедрі організовані бесіди іноземних студентів, які відверто розповідають про ті труднощі, які чекають майбутніх випускників при працевлаштуванні в тих країнах, з яких наше суспільство бере зразок під час реформування системи медичної допомоги в Україні. Це досить ефективно стимулює вітчизняних студентів підвищити мотивацію до опанування неврології.

\section{Література}

1. Запорожан В. М. Міжнародне науково-освітнє співтовариство як каталізатор реформування / В. М. Запорожан, В. Й. Кресюн, О. В. Чернецька // Медична освіта. - 2009. № 2. - С. 34-36.

2. Деякі особливості індивідуальної та самостійної роботи студентів-іноземців під час викладання курсу нервових
}

Висновки. Система підвищення мотивації до навчання грунтується, в першу чергу, на тісному зв' язку з засобами масової інформації, в другу - попередньому зв'язку з середніми навчальними закладами, та в третю - підвищенням якості підготовки викладачів, i націлена в майбутнє медицини після іiї реформування.

Якість опанування студентами курсу нервових хвороб в 2008 - 2010 роках значно покращилась.

Таким чином, заходи, які приймає ОНМедУ і кафедра нейрохірургії і неврології щодо підвищення мотивації студентів до навчання, дають можливість:

- підвищити якість лікувально-навчального процеcy;

- в період демографічного спаду зробити більш якісний попередній відбір студентів в загальноосвітніх школах;

- студентам раніше визначитися з фаховим направленням подальшої роботи;

- зменшити відсів студентів під час навчання, так і в ході подальшої професійної діяльності;

- для іноземних студентів такий підхід дає можливість більш ефективно конкурувати на лікарському ринку праці в себе вдома.

хвороб / А. С. Сон, В. В. Добровольський, Ю. І. Горанський [та ін.] // Медична освіта. -2009. - № 4. - С. 25-28.

3. Панчишин С. Конкурентоспроможність робочої сили у відкритій господарській системі України / С. Панчишин, О. Сахарська// Вісник Львівського університету. Серія екон. -2009. - Вип. 41.-С. 3-7. 